\title{
RECENT ACQUISITIONS OF THE WILLIAM COBBETT COLLECTION IN THE RUTGERS UNIVERSITY LIBRARY
}

\author{
BY JOHN W. OSBORNE
}

Dr. Osborne is a member of the faculty of the Newark State College.

LTHOUGH the death of Professor C. Rexford Davis in
August, I957 removed a devoted scholar whose efforts were largely responsible for the outstanding collection of Cobbettiana now in the Special Collections of Rutgers University Library, the staff has not lost interest in the acquisition of new items concerning the life and writings of William Cobbett. During the past few years, acquisitions have included not only writings by Cobbett, but also outstanding examples of the literature known as "anti-Cobbett." The latter are attacks on Cobbett by his journalistic enemies. Among them is a pamphlet, Cobbett's Penny Trash (a satire on Cobbett's own Two-Penmy Trash), issue of February, March and April, I 83 I. This publication is typical in that it takes Cobbett to task for the numerous inconsistencies which were alleged to mark his career. ${ }^{1}$ The charge is all too true if one is content simply to examine Cobbett's shifting political and economic attitudes. Passionate and easily aroused, he often committed himself to a point of view which he eventually abandoned. However, there was no inconsistency in his championing of the welfare of the common people. This was the essence of Cobbett's writings; the various and shifting means were mere accidents.

The Democratic Quartetto ${ }^{2}$ was written in 1808 and attacked Cobbett for supporting a parliamentary investigation into charges made by Major Denis Hogan that a certain Mrs. Clarke, mistress of

${ }^{1}$ Cobbett's Penny Trash, Roake and Varty, n.n., n.d. The printer was T. C. Hansard to whom Cobbett had to sell his compilation of the proceedings of Parliament while in difficult financial circumstances during the year i 8 r r. Now known as Hansard's Parliamentary Debates, the original idea and execution of the scheme was Cobbett's.

${ }^{2}$ Full title: The Democratic Quartetto: or, Physic for the Friends; an excellent remedy against the Seditious Hydrophobia, administered to William Cobbett, Denis Hogan, Peter Finnerty, and Gale Jones; with an Additional Dose for the Independent Whig, London, C. Chapple, 1808 . 
the Duke of York, was using her lover's position as Commander-inChief of the army to conduct a brisk trade in army commissions. The Duke's friends tried unsuccessfully to suppress the investigation but an enquiry was held which resulted in the acquittal of the Duke on the charge of personal corruption. However, the case of the Duke and his "Darling Love" was the main topic of popular interest at the time. ${ }^{3}$ The scandal caused the Duke of York to resign as Commander-in-Chief. In its stress upon an emotional, unquestioning loyalty, and disregard for facts, The Democratic Quartetto is a typical example of writings in support of the royal family which were current at the time.

Cobbett was the subject of a satirical poem called "Horace in Parliament" (a thrust at his love of rural life) in The New AntiJacobin, a monthly magazine which covered politics, commerce, science and the arts. ${ }^{4}$ This magazine was an attempt to copy the highly successful Anti-Jacobin, the Tory journal through which the young George Canning achieved fame and fortune. Among other items was a virulent anti-semitic attack upon a young novelist and hopeful politician named Benjamin Disraeli. The magazine also contained an article which condemned industrialism for bringing misery to the workers.

Another volume, the Spirit of the Age Nerespaper for 1828 , contains selections from The Age, a weekly journal of strong Tory convictions ("we are Tory of the Tories. .."), the hero of which was the reactionary Lord Chancellor, Eldon. Like many publications of extreme views, The Age was more concerned with chastising members of the same general belief for lukewarmness than in dealing with the common enemy. Only a couple of references to Cobbett can be found here but the book is interesting for its puns and ponderous humor, its allusions to writers of ancient Greece and Rome, and its sneers at all forms of progress, including "Cockney College" (the newly-founded University of London).$^{5}$ Cobbett, by the way, de-

\footnotetext{
${ }^{3}$ Instead of tossing "heads and tails" in the streets, it was "Duke and Darling." See Fremantle, A. F., England in the Nineteenth Century, I806-1 $_{10} 0$, London, George Allen and Unwin, Ltd., 1930, pp. 26 I-262.

${ }^{4}$ There is also an interesting, if somewhat crudely drawn, sketch of Cobbett, then over seventy years of age, in the bound volume which the library now possesses. The New Anti-Jacobin, London, Smith, Elder and Co., 1833 , pp. 142-143.

${ }^{5}$ Spirit of the Age Nerwspaper, London, A. Durham, 1829 .
} 
lighted in journalistic controversy and could more than hold his own in the vigorous exchange of insults which marked debate at the time. "He who uses the press ought to defend himself solely with the press," he remarked, scorning those who resorted to the courts to defend themselves against the sallies of their rivals. ${ }^{6}$

Since I 957 Rutgers has secured a representative sample of Cobbett's own writings. Two comparatively minor items, The Ninth Letter to Lord Harokesbury Relative to the Peace with Bonaparte and The Pride of Britannia Humbled, are contained in the Cobbett collection in other editions. The former publication was written in 1802 while Cobbett was urging that the war against France be conducted with more vigor than he felt the Foreign Secretary, Lord Hawkesbury, was capable of manifesting. The second item was written in 1816 after he had become the outspoken critic of the Tory ministry and all its policies, foreign and domestic. It was designed to show that the defeats suffered by Great Britain during the War of I 8 I 2 were due to the incompetence and extravagance of the government in London. This was a favorite theme of Cobbett at the time and he was fond of contrasting the Tory leadership with the rather idealized picture that he had of the honest and homespun American statesmen. It is not surprising that an American publisher brought out an edition of this work. ${ }^{8}$

Somewhat more important, in terms of Cobbett's career, are editions of three of his best known writings, Cobbett's Poor Man's Friend, A History of the Protestant Reformation in England and Ireland and Cobbett's Legacy to Parsons. Cobbett termed the Poor Man's Friend the favorite thing that he had ever written. It would be an ideal introduction to Cobbett's thought for anyone who has never ventured to read him. Both in the succinct clarity of its style and the profound sympathy which it exhibits for the problems of the common man, the book represents Cobbett at his best. Quite different is his History of the Protestant Reformation, of which there have been many editions. This curious book can only be understood in the light

${ }^{6}$ Cobbett's Political Register (8/20|08), cols. 269-27 I.

${ }^{7}$ Later to be known as Lord Liverpool and to serve as Prime Minister from 18 i 2 to 1827 .

${ }^{8}$ The Ninth Letter to Lord Hawkesbury Relative to the Peace with Bonaparte, Philadelphia, B. Davies, I802; The Pride of Britannia Humbled, Cincinnati, Williams and Mason, 1817 . 
of Cobbett's principal conviction: that the once happy and abundant life of the English laborer had been ended by an evil conspiracy which brought to power a class of stockbrokers, bankers and government creditors. The old landowning aristocracy, which felt a warm attachment toward their tenants and laborers, had been impoverished or had sold out to commercial interests. Cobbett traced this process back to the Reformation. As a result he became an ardent supporter of Catholic interests, while never relinquishing his Anglican beliefs. Noted for its vigorous attacks upon the personalities and deeds of Henry VIII and Elizabeth I, the History is a good indication of Cobbett's point of view about the subject, but as serious scholarship, it is not acceptable. ${ }^{9}$

Near the end of his life Cobbett wrote a series of tracts which resemble missals. These "Legacy" books were an attempt to summarize in a few words his mature views, which would have been elaborated had he lived. The following dedication to Blomfield, Bishop of London, in Cobbett's Legacy to Parsons is illustrative.

Bishop,

About six-and-twenty years ago, you drank tea at my house at Botley, when you were a curate of some place in Norfolk; or a teacher to the offspring of some hereditary legislator. How rugged has my course been since that time: how thickly has my path been strewed with thorns! How smooth, how flowery, how pleasant, your career! Yet, here we are; you with a mitre on your head, indeed, and crossier in your holy hands; I, at the end of my rugged and thorny path in a situation to have a right, in the name of the millions of this nation, to inquire, not only into your conduct, but into the utility of the very office that you fill. ${ }^{10}$

Here Cobbett indulged in praise for the Church before the Reformation and pointed out examples of decay before suggesting a separation of Church and State. None of these editions was published during his lifetime.

\footnotetext{
${ }^{9}$ Cobbett's Poor Man's Friend, or, A Defence of The Rights of Those who do The Work and fight The Battles, London, William Cobbett, n.d.; A History of the Protestant Reformation in England and Ireland, London, R. and T. Washbourne, Ltd., n.d.

${ }^{10}$ Cobbett's Legacy to Parsons, London, Richardson and Son, 1868. The introduction was dated March 9, i 835 ; a little over three months later Cobbett was dead.
} 
Perhaps the most interesting acquisition, from a bibliographical standpoint, is A Letter, Addressed to Mr. Jabet, of Birmingham. Jabet, a Tory printer, had published an address which urged the poor not to blame their misery upon sinecures or other expenses of the government which necessitated high taxes or to look to parliamentary reform for a remedy. This statement was a reflection of the government policy at the time. The ministers spoke vaguely of recondite economic forces which government action would be powerless to influence and counselled the starving to be patient. Cobbett's reply was characteristically instant and to the point. The tribune of the common people pointed out examples of the use of government power to protect the economic interests of a favored few and went on to denounce extravagance and corruption in the government in general and in the unreformed House of Commons in particular. This particular edition of the Letter is not readily available to purchasers and its acquisition means a valuable addition to the collection. ${ }^{11}$

${ }^{11}$ A Letter, Addressed to Mr. Jabet, of Birmingham, London, J. Aston, 1816. 